$\mathbb{T}$ Periodica Polytechnica

Social and Management

Sciences

25(2), pp. 108-116, 2017

https://doi.org/10.3311/PPso.10459

Creative Commons Attribution (i)

RESEARCH ARTICLE

\section{Key Factors of Disabled People's Working Motivation: an Empirical Study Based on a Hungarian Sample}

\author{
Andrienn Kertész ${ }^{1,2^{*}}$, Beatrix Séllei ${ }^{3}$, Lajos Izsó ${ }^{3}$
}

Received 01 January 2017; accepted after revision 06 April 2017

\begin{abstract}
This paper addresses the background variables influencing the disabled persons' motivation to work. Data collection was carried out in Hungary by experts analyzing the change of capability to work on a nationally representative sample. This allows us to highlight also the regional differences, because the motivational status sharply reflected this geographical impact. Besides the socio-economical status, not only motivational readiness was studied, but also factors responsible for cognitive and emotional immunity. Points of intervention were also identified, where the motivation processes could be catalyzed. The aim of this paper is to provide a concise summary of results, to give tentative interpretations and finally to identify practical intervention possibilities to increase handicapped persons' motivation to work in Hungary.
\end{abstract}

\section{Keyword}

vocational rehabilitation, motivation to work, learned helplessness/resourcefulness

\footnotetext{
${ }^{1}$ Doctoral School of Psychology,

Eötvös Loránd University

${ }^{2}$ Hungarian Defence Forces,

„,vitéz Szurmay Sándor” Budapest Garrison Brigade

${ }^{3}$ Department of Ergonomics and Psychology,

Budapest University of Technology

*Corresponding author, e-mail: kertesza@erg.bme.hu
}

\section{Introduction}

Vocational rehabilitation models can follow either the topdown or the bottom-up approach (Frank and Sawney, 2003). In most countries - including Hungary - both of these two approaches are simultaneously present. From this integrative approach we have to highlight that disability is not necessarily associated with the reduction of ability to work, which can be a basic pillar of vocational rehabilitation. The Hungarian system nicely differentiates this by separating health damages from the reduction of ability to work. The Hungarian state, on the one hand, provides incentives to increase the employment of employees with reduced ability to work, while on the other hand, it penalizes employers if they do not employ a pre-defined number of handicapped persons relative to the total headcount of employees.

It is important to consider, for example, whether the disability is the result of working activity, of accident or it is congenital. These cases call for completely different approaches and effort strategies, because their impact can be different at the different stages of one's career, thus influencing motivation (Séllei, 2010). In addition to placing the handicapped person to the center, it is important to switch to the positive psychological approach that is based on growth and focuses on the remaining abilities the workplace (re)integration can be built on (Chamberlain, 2003; Rusin and Uomoto, 2010).

Helping handicapped persons back to the world of work sets considerable challenges even for the rehabilitation team, the topdown resolution of which is starting to gain ground with the help of government-level organizational changes. On the other hand, the knowledge required for bottom-up career planning of disabled people is also rather significant. The most important factor is the interaction continuously working between the employee, his/her immediate environment and the societal environment (Hershenson, 2005). Do the abilities of a person allow working, if yes, in which areas? Is his/her immediate environment adequate, is the system of rehabilitation appropriate and are the experts able to properly judge the situation? (Wegener and Stiers, 2010).

By integrating all this and taking the Hungarian characteristics into consideration, based on research, practical experience and 
expert opinion, Izsó (2011) has set up the following simple model of the process of returning to work (see on Fig. 1). This model also provides guidance to evaluate the particular requirements.

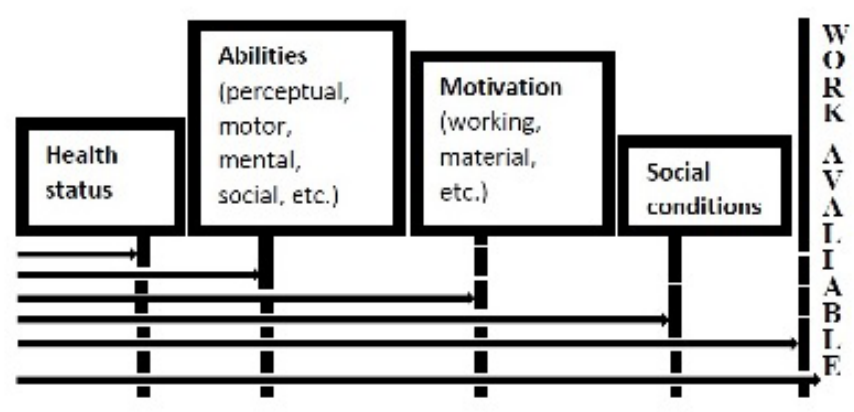

Fig. 1 Process of returning to work: the four main groups of requirements

Having improved his/her abilities, a person can find the most appropriate working place after walking through the process indicated in Fig. 1. The primary task of evaluating the health status (the first group of requirements) falls within the physician's competence, setting guidelines for the determination of the remaining working ability. In order to verify it and to prepare the employment, examinations of work-relevant abilities $^{1}$ (the second group of requirements) are indispensable, upon which considerations the possibility of employment is based. Whenever there are working places available at the end of the process the above mentioned crucial competencies become important. These are psychological characteristics that may overwrite the health status to both positive and negative direction. The strongest impact is that of motivation (the third group of requirements). The status of motivation may partly be related to the socio-economic status and partly to the personality. With respect to motivation, the most relevant factor is how extrinsic or intrinsic it is, and what is the most important agent: the immediate money, the social security, the fear of unemployment, etc. People with reduced ability to work are often motivated by their wish to avoid failure. In order to more efficiently encourage handicapped people to find a job, to cope with their working environment and to perform, we have to find the factors that actually influence their motivation.

There are differences in the motivational status, and these differences are manifested in how the handicapped persons mobilize their external and internal resources, because the psycho-social environment (the fourth group of requirements) together with the physical environment, surrounding a person has a complex impact (Johnson-Greene and Touradji, 2010). All these factors can be gathered into a conceptual frame under the umbrella term of "psychological immunity". This is a kind of

1 These examinations may be extended to partial abilities like perception, smoothly coordinated muscle movements or certain cognitive skills as memory or reasoning. immunity that includes various personality factors and coping methods as a set of cognitive tools, as well as protective dimensions (Oláh, 2005). Our psychological immune system seems to be nourished from many sources, and it definitely influences the ability and willingness to work. Perspective about future and willingness to learn are parts of the coping toolset, which are influenced by the person's personality, pre-morbid or actual characteristics, as well as the changes resulted by the injury. The existence of these resources may buffer the effect of stressful life events, while the lack of them may even worsen the situation (Johnson-Greene and Touradji, 2010).

The work as a tool to achieve well-being is decisive in normal human life. If the work as the basis of independent living is not available for the person, it may cause mental suffering, and in addition to not being able to attain material goods may also lower quality of life, together with the deterioration of mental and physiological health (Kopp and Réthelyi, 2004). This may easily lead to the phenomena of "learned helplessness" (Csabai and Molnár, 1999) that also lowers motivation. This is the proven theory that depression and related mental illnesses may result from a perceived absence of control over the outcome of a situation. Recent Hungarian research data indicate that handicapped people with low education are the most vulnerable to depression, which in turn generates further deterioration of motivation, work performance and family balance thus triggering a tragic circulus vitiosus (Kopp and Skrabski, 2009).

\section{Sample and Methods \\ 2.1 Sample}

The data collecting phase of this research was organized by the National Office for Rehabilitation and Social Affairs [NORSA], between April $1^{\text {st }}$ and July $18^{\text {th }} 2011$.

The data gathered during the $16.431^{2}$ interviews - supported by a preliminarily prepared questionnaire recorded by social affairs specialists of the NORSA - can be taken as coming from a quasi-representative national sample.

Although some basic and general findings from this study have already been published (Pósfai et al., 2013), this paper contains more sophisticated analyses and more concrete results.

With respect to the age distribution, the sample includes people, who are active ${ }^{3}$ from working ability point of view.

2 This number of persons forms a sample large enough to draw conclusions for the whole population of employees with reduced ability in working age, because today 305.323 are registered in Hungary as invalids, based on the data of www.onyf.hu. This sample size is about 10 percent of the annual examinations by NORSA.

3 Between age 18 and the age of superannuation by the right of the act. 


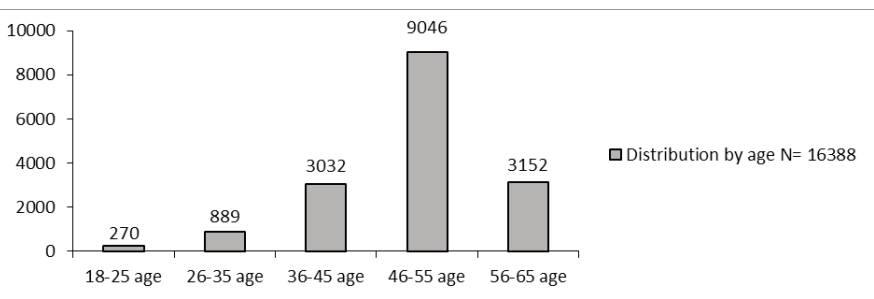

Fig. 2 Distribution by age

Distribution of the decisions of the Committee about recommendation was the following:
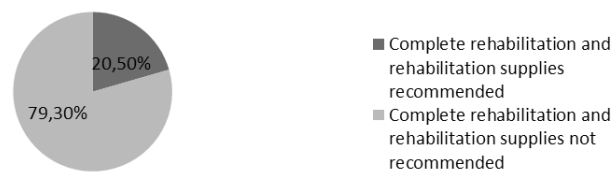

Fig. 3 Distribution of first-level examination by recommendation of the Committee $(\mathrm{N}=13300)$

Considerably less people are recommended for full rehabili-

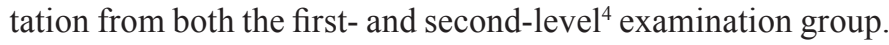
With respect to these groups, 27 percent of the first-level and 18 percent of the second-level examinations are recommended for complex rehabilitation, respectively. The committees operating in the country recommended 9498 people for rehabilitation treatment ${ }^{5}$ in 2011.

\subsection{Methods}

The data were basically analyzed by the following three relevant methods: multinomial logistic regression, artificial neural networks (ANN) and decision trees using the IBM SPSS Statistics 19 package. Since all these three methods produced basically the same results based on models of acceptable accuracy, in the following only the results of ANN analyses are presented. The dependent (target) variable in all analyses was the persons' motivation to work on a three-grade ordinal scale: (1) not motivated, (2) can be motivated and (3) motivated ${ }^{6}$. All the other variables were considered as predictors. In addition to ANN results, in this paper the main results of a causal modeling is also presented. This model was created by the SEM (Structural Equation Modeling) method to safely identify causal relationships using the IBM SPSS AMOS package.

Concerning predictor variables, all the available socioeconomical data of participants (i.e. gender, age, education, status in family, place of living, income) were collected. We also

4 The first-level examination is a real medical examination, but the secondlevel examination is just a legal redress.

5 Between 50-75 percent damage to health.

6 The motivational status was rated by the data collectors. These data were based on the overall impressions of the administrators and came also from the persons consulted.

get some data about the workplace, last position, number of years spent without work, etc. in case of actual unemployment. About the communication, mobility, motivation, health status and emotional status or skills, indirect data were collected from the interviewers. The variables used in the artificial neural networks (ANN, MLP) analysis are summarized below in Table 1.

Table 1 The variables used in the artificial neural networks analysis.

\begin{tabular}{|c|c|c|}
\hline Variable name & Variable label & $\begin{array}{l}\text { Variable } \\
\text { level }\end{array}$ \\
\hline $\begin{array}{l}\text { motivation } \\
\text { (target variabale) }\end{array}$ & motivation of interviewee & Ordinal \\
\hline gender & gender of interviewee & Nominal \\
\hline age & age of interviewee & Ordinal \\
\hline lives_alone & interviewee lives alone & Nominal \\
\hline lives_with_children & $\begin{array}{l}\text { interviewee lives with } \\
\text { children }\end{array}$ & Nominal \\
\hline lives_with_parents & $\begin{array}{l}\text { interviewee lives with } \\
\text { parents }\end{array}$ & Nominal \\
\hline lives_with_spouse & $\begin{array}{l}\text { interviewee lives with } \\
\text { spouse }\end{array}$ & Nominal \\
\hline status_in_family & $\begin{array}{l}\text { interviewee's status in } \\
\text { family }\end{array}$ & Nominal \\
\hline $\begin{array}{l}\text { number_of_minors_in_ } \\
\text { family }\end{array}$ & $\begin{array}{l}\text { number of minors (under } \\
\text { age) in family }\end{array}$ & Scale \\
\hline $\begin{array}{l}\text { number_of_earners_in_ } \\
\text { family }\end{array}$ & $\begin{array}{l}\text { number of wage-earners in } \\
\text { family }\end{array}$ & Scale \\
\hline $\begin{array}{l}\text { number_of_unemployed_ } \\
\text { in_family }\end{array}$ & $\begin{array}{l}\text { number of uneployed } \\
\text { persons in family }\end{array}$ & Scale \\
\hline $\begin{array}{l}\text { number_of_pensioners_in } \\
\text { family }\end{array}$ & $\begin{array}{l}\text { number of pensioners in } \\
\text { family }\end{array}$ & Scale \\
\hline $\begin{array}{l}\text { number_of_dependents_ } \\
\text { in_family }\end{array}$ & $\begin{array}{l}\text { number of dependents in } \\
\text { family }\end{array}$ & Scale \\
\hline county & $\begin{array}{l}\text { county where interviewee } \\
\text { lives }\end{array}$ & Nominal \\
\hline living_place & $\begin{array}{l}\text { place where the interviewee } \\
\text { lives }\end{array}$ & Ordinal \\
\hline type_of_accommodation & $\begin{array}{l}\text { type of accommodation } \\
\text { where the interviewee lives }\end{array}$ & Ordinal \\
\hline comfort_of_accommodation & $\begin{array}{l}\text { degree of comfort of } \\
\text { accommodation where the } \\
\text { interviewee lives }\end{array}$ & Ordinal \\
\hline $\begin{array}{l}\text { ownership_of_accommo- } \\
\text { dation }\end{array}$ & $\begin{array}{l}\text { ownership of } \\
\text { accommodation where the } \\
\text { interviewee lives }\end{array}$ & Ordinal \\
\hline level_of_education & $\begin{array}{l}\text { level of education of the } \\
\text { interviewee }\end{array}$ & Ordinal \\
\hline years_spent_in_work & $\begin{array}{l}\text { years spent in work by the } \\
\text { interviewee }\end{array}$ & Ordinal \\
\hline years_without_work & $\begin{array}{l}\text { years spent without work by } \\
\text { the interviewee }\end{array}$ & Ordinal \\
\hline last_position & $\begin{array}{l}\text { last position occupied by the } \\
\text { interviewee }\end{array}$ & Ordinal \\
\hline
\end{tabular}




\section{Results}

\subsection{Results of ANN analyses}

\subsubsection{Results at national level}

The results produced by ANN method can be seen below in Fig. 4, 5 and 6. As in the expressive graphical output (Fig. 4) it is shown, at whole country level the normalized importance of the variable "years without work" is far the most important predictor that decreases motivation, very probably due to the "learned helplessness". Among the other, relatively less important predictors, are those that relate to the socio-economic status and the support by the family (number of pensioners in family, status in family, number of earners/dependents/minors in family, level of education, living place, living alone etc.), as well as the age of the person.

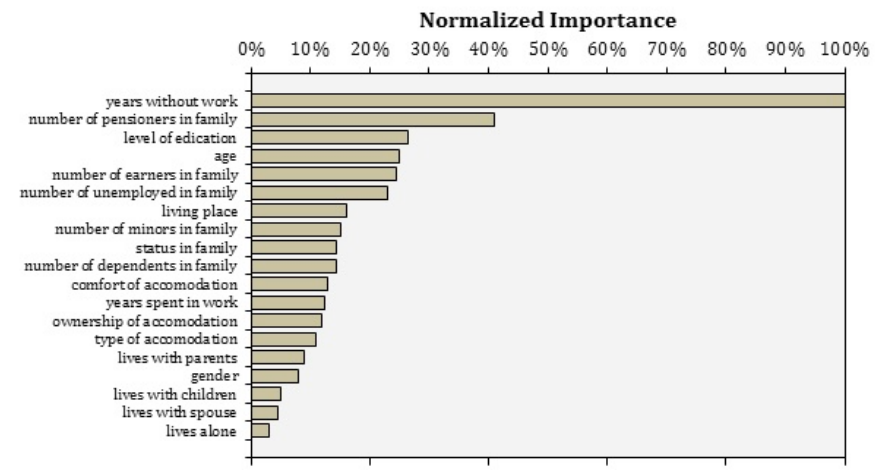

Fig. 4 The normalized importance of the predictors at country level produced by the artificial neural networks model (ANN MLP)

Most of the counties show results very similar to the nationwide data, there are only minor differences in the order of the predictors determining motivation. On the other hand, what is worth analysing separately, there are two counties showing extreme values regarding motivation; while the ratio of unmotivated people is 42.8 nationally, the same is 68 percent in Nógrád County, and only 23 percent in Vas County.

It was proven that the higher the ratio of the motivated people in the sub-sample, the more accurate the estimate given by the ANN MLP model for the predictors will be for the 'motivation' target variable. It is interesting to note in Fig. 5 that the other variable significantly stay behind the importance of the number of years spent without work, and their strength vary between 1 and 30 percent. So the experiences in work or job-seeking are the most important background factors of the motivational status and the socio-economic status seems to be not so determining.

\subsubsection{Results at Vas County level}

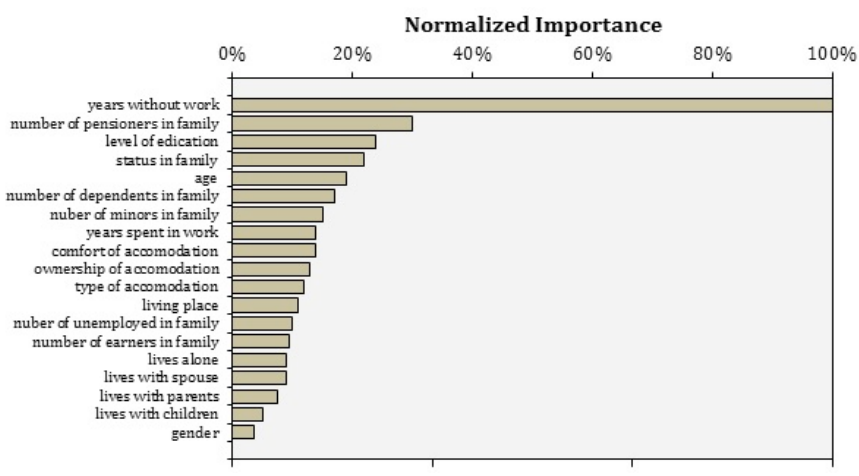

Fig. 5 The normalized importance of the predictors produced by the artificial neural networks model in county Vas

From the point of view of motivation, the number of years spent without work has the highest importance, with the increase of years spent without work, the motivation is reduced $(\beta=-.512, \mathrm{p}<0,05)$. This will still be stabilized on a higher basic level than in the less motivated county, see Fig. 6.

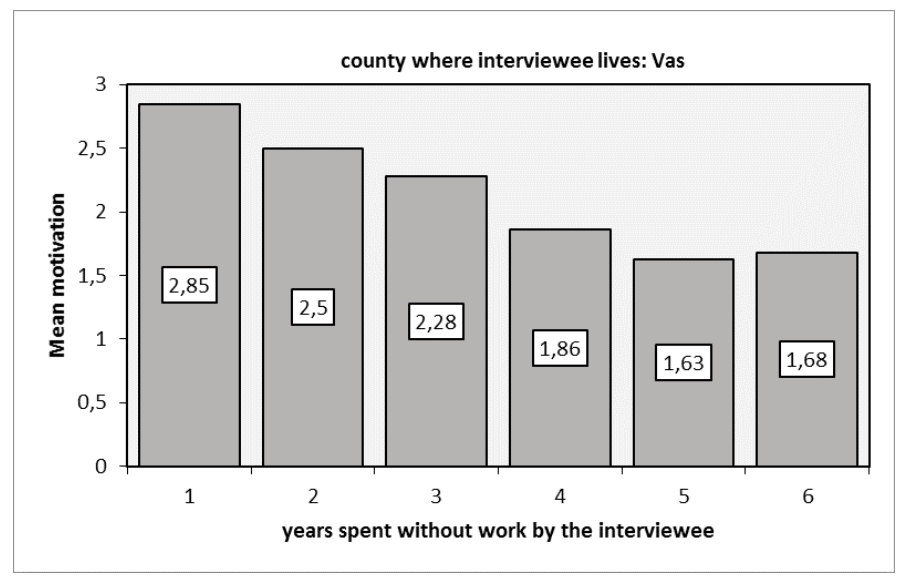

Fig. 6 Change of motivation readiness depending on the number of years spent without work in Vas County

One can well see the impact of learned helplessness, as the person learns during the years of hopelessly looking for work that he/she is not in control of his/her own environment and his/ her own fate - and this feeling may lead to giving up responsibility, or even to depression.

For saving room, in this section and in the following of this paper only the whole country level and the Vas county level results are presented. Vas county was selected since it is the ost highly motivated county

\subsection{Results of SEM analyses}

The professional support (provided by NORSA) allows us to establish well-grounded SEM causality models as well, based on the above data, because this is why we considered important to efficiently determine the possible intervention points. 
In social sciences, we use a lot of variables that are dichotomous or ordered categorical rather than truly continuous. In this fact, it is normal that the distribution of observed variables departs substantially from multivariate normality. Although neither the applied predictors, nor the distribution of the target variable could be considered normal, we were able to create a very good model using the procedure of the IBM SPSS AMOS program package developed for such cases (asymptotically distribution free (ADF) estimation) - taking advantage of the high number of elements $(\mathrm{N}=16431)$, see Fig. 7.

\section{Results at National level}

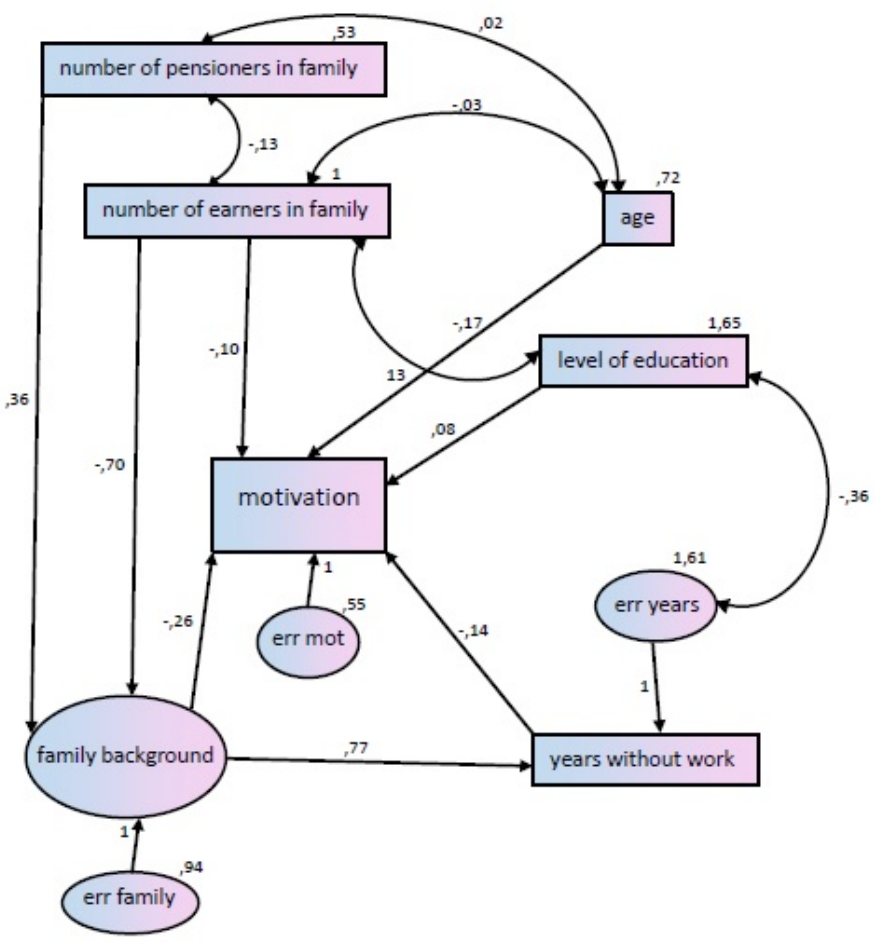

Fig. 7 Causality model of factors determining motivation on national level $(\mathrm{N}=16431)$. As generally accepted in SEM modelling, rectangles represent the observed (manifest) variables, and the ellipses the unobserved (latent) variables. Thus family background is a latent construct involving which into the model radically improved the fit indices. The numbers near to the single-headed arrows, representing linear dependencies, are regression beta coefficients. The numbers near to the double-headed arrows, however, are linear correlation coefficients.

This model can be seen as identified $(\mathrm{DF}=3)$, and it is very well aligned $(\mathrm{CMIN}=4.227, \mathrm{DF}=3, \mathrm{CMIN} / \mathrm{DF}=1.409, \mathrm{p}=.238$ RMSEA $=.005$, confidence interval $90 \%$ PCLOSE $=1,000$, $\mathrm{CFI}=1.000$, TLI $=.915$ ), and the strong coefficient $\beta$ and the correlation coefficient values makes it interpretable. A general finding is that we can determine a few variables that may support or prevent motivation. Our goal was to ensure that these are well-defined objective, factual variables, and as the model shows, these variables affect motivation both directly by themselves and in indirect way due to their relation to the other variables.
Reviewing the preventing factors, the most significant ones of them seems to be the "pull-back force" of the family background $(\beta=-.26, p<0.05)$, the age $(\beta=-.17, p<0.05)$, the number of years spent unemployed $(\beta=-.14, p<0.05)$, as well as the number of earners in family $(\beta=-.10, p<0.05)$. One also should note how significant impact the family background has on the working experiences $(\beta=.77, p<0.05)$, i.e. what behavioural model the person sees in the family, and what external opportunities a person's competences could meet.

The number of pensioners in the family and the number of earners in the family have significant and from the aspect of motivation opposite to each other impact on the pull-back force of the family background. If there are more pensioners in the family, than the "pull-back force" will increase, that's why in an indirect way the motivation will decrease. The number of earners in the family decrease the "pull-back force" of family background, and thus indirectly increases the motivation. The most probable explanation of which is the fact that employed family members serve as respective models for the others, i.e. work is regarded as a value in the family environment $(\beta=-.70$, $\mathrm{p}<0.05)$. From the model it is identifiable that the number of earners in the family decrease the motivation in a direct way $(\beta=-.10, p<0.05)$. The most probable explanation for this is that the family is somewhat not in need of additional revenue higher than the amount of the disability allowance.

Impeding factors also include the age $(\beta=-.17 p<0.05)$, which partly can be explained with the fact that in Hungary, with the increase of age it becomes increasingly difficult to find work, so they may have more negative experience; on the other hand, older people are less capable of adapting and learning.

Such strong and independent impact of the number of years spent unemployed $(\beta=-.14, p<0.05)$ supports again the emergence of learned helplessness.

The level of education is a factor supporting motivation $(\beta=.08, \mathrm{p}<0.05)$. The dispersion is smaller among the members of the sample with higher education, while for the larger part of the sample it is more difficult to make estimates regarding unemployment. It is generally true that people with higher education are in better position on the labour market and can find work more easily; on the other hand, people with higher education probably have a more mature personality, so they are also more open and flexible, as well.

\section{Results at Vas County level}

Factors considered significant on national level slightly differently contribute to the situation in Vas County, which is the most highly motivated county. Since the fitting indicators of the model are good $(\mathrm{CMIN}=4.860, \mathrm{DF}=2, \mathrm{CMIN} /$ $\mathrm{DF}=2.430, \mathrm{p}=0.88, \mathrm{RMSEA}=.051$, confidence interval $90 \%$ PCLOSE $=.398$. CFI=.989, TLI=.917), we did not feel the necessity of building a more complex model with involving other variables. 
The most significant factor is again the number of years spent unemployed, strongly influenced by the family background. At first sight it seems to surprising, but after careful consideration it is clear that compared to the national values, the strength of the relative impacts in this county of 'good example' is almost reversed. For example the impact of education level is weaker than on national level.

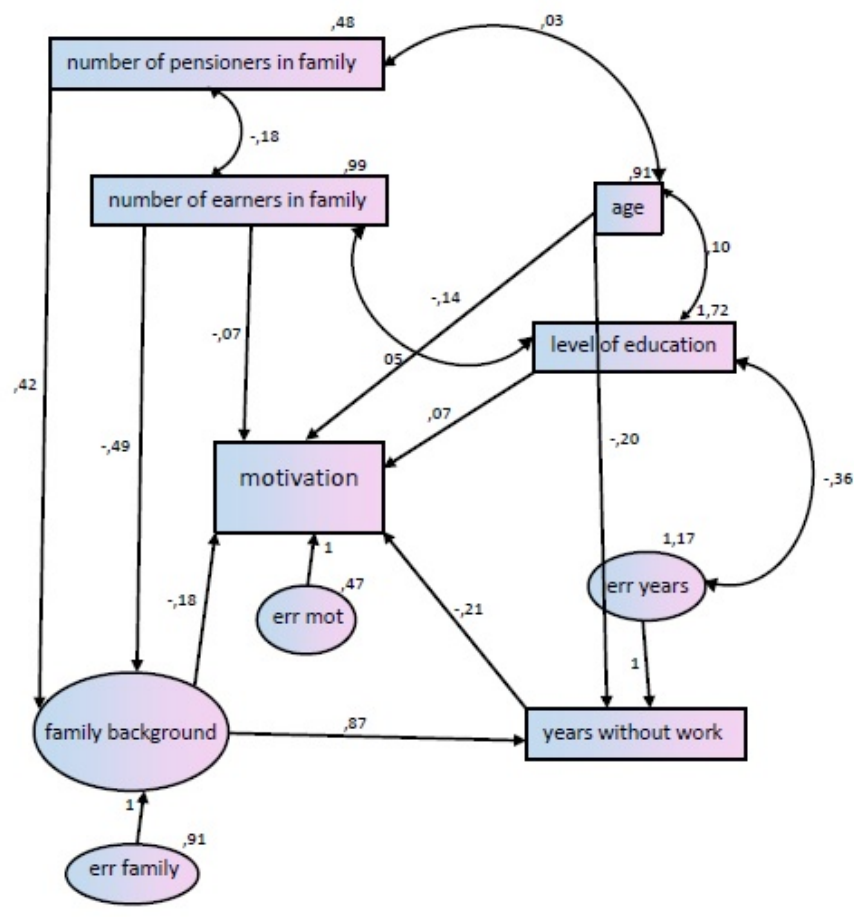

Fig. 8 Causality Causality model of the factors determining motivation in Vas County $(\mathrm{N}=561)$

All indicators of the model lead to the conclusion that from the aspect of motivation, the learned helplessness has the most destructive impact. During the years spent without work $(\beta=-.21, p<0.05)$ a person's confidence in his/her own competence continues to diminish, which process may be further strengthened by the impact of the family background $(\beta=.87$, $\mathrm{p}<0.05)$.

In county Vas a typical person sees that everybody around him works, even regardless to their education level - as we can see - probably due to the broader scope of available jobs and the average higher education level- the impact of skills on the motivation is much lower, than the national average $(\beta=.07$, $\mathrm{p}<0.05$ ). The "pull-back force" of the family background is weaker, probably because there are only few families in this county, where the adequate work socialization model is not available.

\section{Conclusion}

Analyses performed for all counties show that the keys to motivation are the skills, the years spent unemployed and the socio-economic situation of the family.

\subsection{Influence of level of education}

Education always determines motivational readiness, in most cases directly and partly in connection with it, the labour force market opportunities as well. When we review the normalized importance values of the motivation predictors, at national level - whereas these values in the individual counties are similar - level of education has about 27 percent importance.

It is natural that the population is heterogeneous from education point of view, but analyses show that here the distribution peaks to the left: there are significantly more handicapped people graduating from vocational schools only, than handicapped people having higher levels of education.

The first step in this initial situation is to motivate people to take part in education, the key to which is to offer them professional training or retraining courses that are valuable on the labour force market. Just like in Western Europe, in Hungary there is an increasing shortage of people doing skilled labour, so more people can be granted work with simple and practice-oriented training courses. There could be some opportunities where the disabled people can try their abilities and based on this experience they would be more efficient by the job seeking.

Furthermore, training courses improving social or communications competences, or various consultancies can also be listed in this category. We can reckon among this category the language learning also.

The education might be important by the prevention too, because the learning process itself increases the repertoire of coping methods. If a person has higher level of education, she or he could be more open to the world and has more social relationships.

\subsection{Influence of years spent without work}

All analyses of the motivation level attributed significant importance to the number of years spent without work. If we look at the national average, see Fig. 9, we can see gradual decrease $(\beta=-.457, \mathrm{p}<0.05)$.

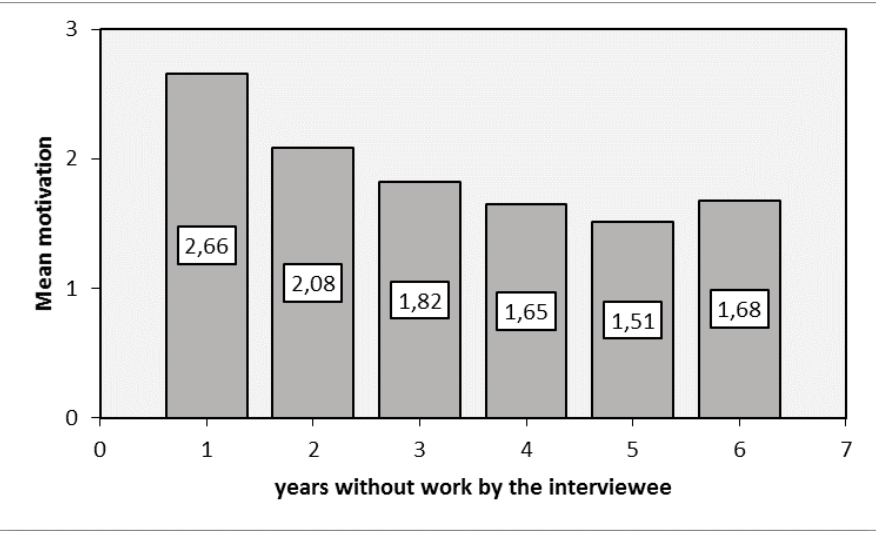

Fig. 9 Decreasing motivation level due to the years spent without work at national level 
This trend may refer to giving up and the formation of learned helplessness. At the same time, a slight increase of motivation can be observed in year 6 , which may refer to the fact that a small share of people has the ability to re-motivate themselves later. It is worth considering that if this impact is due to the benefits granted to permanently unemployed people, then it would be reasonable to introduce these benefits as soon as possible.

We can also observe that motivation starts decreasing significantly already during the first year, so the resources could also be concentrated to preserve jobs, just like in case of protected employees (even due to their age), when employers have to indicate more criteria to fire them. This way, handicapped people would not have to go through a status change (e.g. from employed to dependent), which important not only from self-image and self-esteem aspects, but also prevents the formation of learned helplessness. This can be regarded as a kind of pro-active attitude that may help preventing negative impacts of unemployment observed already in short term.

The main goal should be to help people to keep their job with the help of governmental provisions. The more negative experience the unemployed people get by the job seeking progress either about their competence or about the job searching itself, the more likely is the start of a self-damaging turnover progress. At this point, the role of the prevention is primary, related with the education of the person (for example conscious career-planning and life coaching). In this educational process the rehabilitation counsellors can take part.

\subsection{Influence of family background}

Concerning the socio-economic status not only the above factors, but also the economic situation of the family is a significant factor. Unfortunately, the supply system providing material and social support to handicapped people currently does not operate satisfactorily. Although the budgetary resources allocated to this area are limited, this scope also includes social support, which represents a kind of social protection net.

The necessity of this is also supported by the analysis that also involved soft variables into the ANN MLP model, and the outcome was that a supporting family and an assistive environmental background have great significance. Reclusion, learned helplessness and eventually the lack of motivation will generate more difficulties in a thoughtful and supporting community. Although these relationships are mostly informal, but could be established in formal frames as well.

There is an important factor what is hardly changeable: the family background. Beside the governmental support system we propose the establishment of local social networks and (self)helping groups. The cohesion and the keeping effect of smaller social groups can have an important role.

\subsection{Proposed interventions: strategic planning}

During the determination of interventions, the most important factor is conscious and systemic planning. A system treating handicapped people as active participants and focusing on health awareness should be developed. For this purpose, health means physical and mental welfare, which - according to the WHO definition - is more than simply the lack of diseases (1984). For example, from the aspect of subjective welfare, a chronic hypertension may become irrelevant, if not accompanied by negative stereotypes on behalf of the society specifically including in this case the employers.

Looking at a bigger picture in health improvement, we have to direct our thinking toward social, economic and environmental directions (Ewels and Simnett, 1996), which appears on individual level in the factors we have already identified, such as a supporting family background, but we can also set parallels with the health determinants defined by WHO.

As we wish to achieve a complex impact, interventions are also possible on various levels. In our case, medical and preventive measures are the least emphatic, as opposed to the approach aiming at behavioural change, education and information provision, focusing on the client at the same time. Activity of the participating person increases the confidence in his/her competence, thus preventing the reduction of motivation. We cannot, however, state that this could be achieved without social changes and measures. To achieve this, programs are necessary that are in harmony with the objectives of international and European organizations, but can be broken down to programs defined for individual countries or even regions and settlements (Ewels and Simnett, 1996), because - as we have already seen - different factors determine motivation even within the same country. If the individual systems were interoperable and compatible with each other, and would work as teams at all levels, professional organizations with broad scope of authority could establish research programs and formulate the related practical information.

Such initiatives are for example, the Rehabilitation Information Centres in all counties serving authentic and adequate information flow. To use them, in most cases certain level of education, motivation and workplace support are necessary. So a service system would have to be restructured, where the access is not optional, and where people can obtain information about legal provisions, use career consultation and job searching support services, aid supply all at the same place, and where all necessary information are available.

The three key factors defined above helps us not only to develop the said programs, but also to response more quickly to the acute problems, e.g. by identifying risk groups. In the supply system we obviously have to give priority to the handicapped persons, who have been unemployed for a longer time, 
have lower education, are of older age, have poor socio-economic status, and reside in a region of the country, where the employment situation is rather bad.

As a summary, we can find that the research has set important directions: we were able to explore the differences of work motivation of handicapped people living in the different counties of the country, and to prepare preliminary plans on this basis to increase motivation - and consequently the employment on longer term. Our research identified similar factors preventing return to work, as Holmes $(2007$, p.87.) based on Waddel and Alward (2005), see Table 2 below.

Table 2 Multifactorial obstactles in returning to work (Holmes, 2007., p.87)

Age, gender, family and social background

\begin{tabular}{ll}
$\begin{array}{l}\text { Personal } \\
\text { characteristics }\end{array}$ & $\begin{array}{l}\text { Education, training and skills, work history a } \\
\text { experience } \\
\text { Physical or mental condition, impairment an } \\
\text { functional limits }\end{array}$ \\
\hline & Personal expreince of illness and disability \\
& Perceptions and expectations \\
Psychological & $\begin{array}{l}\text { Attitudes, beliefs, emotions, mood, coping } \\
\text { strategies }\end{array}$ \\
& Motivation, effort, incentives \\
& Uncertainty
\end{tabular}

Culture, surrounding health, sickness, disability and work

Labour market forces

Social factors

Social and occupational barriers

Discrimination, social exclusion

Financial (dis)incentive

This way we can draw an analogy also with the intervention levels and opportunities defined by them. All sectors have to be involved in the process of return to work, from the training locations to insurance companies and beyond the government and societal levels, even volunteers; employers and the private sector have also take seriously part in this - depending on the actual stage of the person in the return process (Holmes, 2007). In Hungary - except for explicitly protected jobs - this is the least efficient process, though this is one of the two key factors of employment. The related interventions - even in connection with the workplace or work task - show beyond the scope of this paper.

Physical and mental health and social interventions are very important in the process of returning to work. We have to distinguish the following three stages: (1) managing and improving health for work, the use of support on both medical and behavioural levels; (2) getting ready for work, to prepare for work once again, exercise and learn, and (3) managing and improving social issues for work, the person is again responsible for his/her own life, (Holmes, 2007).
Nevertheless, our analysis leads to the conclusion that primary focus has to be given to the preservation of jobs, preventing the people of our target group from falling out of the world of work as a result of their changed work capabilities. In order to implement this primary prevention, further positive discrimination principles codified in laws and decrees are necessary.

\subsection{Strengths and limits of the study}

The most important advantage of this study is the size of the sample which is big enough to be representative on national level to the people with changed working ability in Hungary. So based on this study valid conclusions can be drawn concerning this population. Other advantage of this study is that the sample was collected randomly, all of the people with disabilities had equal opportunities to be the part of the sample.

A notable limit of this study is the way how we got the data: in seconder form, it means that we didn't take part in the design of the survey. Therefore we couldn't control the progress of data collection and coding. Actually it is not really a serious problem in case of the hard (factual) data but in the case of the soft data we had certain doubts. To avoid the potential misunderstandings and solve our solicitudes we made clarifying discussions with the supervisors of the interviewers.

\section{Acknowledgement}

We wish to express our gratitude to Dr Gábor Pósfai, who as the head of the National Office of Rehabilitation and Social Affairs - had made the interview raw data available to us. We also wish to thank the personnel of this Office for their hard work by the data collection and coding progress.

\section{References}

Chamberlain, M. A. (2007). Work, disability and rehabilitation: making the best job of it. Clinical Medicine. 7(6), pp. 603-606. https://doi.org/10.7861/clinmedicine.7-6-603

Csabai, M., Molnár, P. (1999). Egészség, betegség, gyógyítás - Az orvosi pszichológia tankönyve. (Health, illness, healing - Handbook of psychology for medicine). Springer Orvosi Kiadó Kft., Budapest (in Hungarian).

Ewels, L., Simnett, I. (1996). Promoting Health. A practical Guide. Baillière Tindall, London.

Frank, A. O., Sawney, P. (2003). Vocational rehabilitation. Journal of the Royal Society of Medicine. 96(11), pp. 522-524.

Hershenson, D. D. (2005). INCOME: a culturally inclusive and disability-sensitive framework for organizing career development concepts and interventions. Career Development Quarterly. 54(2), pp. 150-161. URL: http://www.freepatentsonline.com/article/Career-Development-Quarterly/140564353.html

Holmes, J. (2007). Vocational Rehabilitation. Blackwell Publishing, Oxford. Izsó, L. (2011). Personal communication.

Johnson-Greene, D., Touradji, P. (2010). Assessment of Personality and Psychopathology. In: Frank, R. G., Rosenthal, M., Caplan, B. (eds.) Handbook of Rehabilitation Psychology. (pp. 195-212.) American Psychological Association, Washington DC. 
Kertész, A. (2010). A munkahelyi elégedettséget befolyásoló tényezők. In: Juhász, M. (ed.) A foglalkozási rehabilitáció támogatása pszichológiai eszközökkel. (pp. 289-302.) Typotex, Budapest. (in Hungarian).

Kopp, M., Réthelyi, J. (2004). Where psychology meets physiology: chronic stress and premature mortality - the Central-Eastern European health paradox. Brain Research Bulletin. 62(5), pp. 351-367. https://doi.org/10.1016/j.brainresbull.2003.12.001

Kopp, M., Skrabski Á. (2009). Magyar lelkiállapot az ezredforduló után. (Hugarian state of mind after the millennium.), Távlatok: világnézet, lelkiség, kultúra. 19(86), pp. 32-52. (in Hungarian).

URL: http://www.tavlatok.hu/86/86kopp_skrabski.pdf

Oláh, A. (2005). Érzelmek, megküzdés és optimális élmény. (Emotions, coping and optimal experience.), Trefort Kiadó, Budapest (in Hungarian).

Pósfai, G., Séllei, B., Kertész, A. (2013). A megváltozott munkaképességủ emberek munkamotivációját befolyásoló kognitív és érzelmi tényezők. Alkalmazott Pszichológia. 13(4), pp. 47-57.

Rusin, M. J., Uomoto, J. M. (2010): Psychotherapeutic Interventions. In: Frank, R. G., Rosenthal, M., Caplan, B. (eds.) Handbook of Rehabilitation Psychology. (pp. 259-272.) American Psychological Association, Washnington, DC.
Séllei, B. (2010). A megváltozott munkaképességủ személyek karrierépítését akadályozó és segítő tényezők. (Barreirs and supporting factors of handicapped persons' carrier). In: Juhász, M. (ed.) A foglalkozási rehabilitáció támogatása pszichológiai eszközökkel. (Psychological support of vocational reabilitation). (pp. 303-329.) Typotex Kiadó, Budapest. (in Hungarian).

Waddel, G., Alward, M. (2005). The scientific and conceptual basis of incapacity benefits. The Stationery Office, London.

Wegener, S.T., Stiers, W. (2010). Prevention, Assessment, and Management of Work-Related Injury and Disability. In: Frank, R. G., Rosenthal, M., Caplan, B. (eds.) Handbook of Rehabilitation Psychology. (pp. 407-416.) American Psychological Association, Washington, DC.

World Health Organisation (1984). Health Promotion: a WHO discussion document on the Concepts and Principles. Reprint. Journal of the Institute of Health Education. 23(1), pp. 5-9. https://doi.org/10.1080/03073289.1985.10805577 